( С. М. Зигуля, к.т.н., доцент, КПІ ім. Ігоря Сікорського, Київ, Україна

\title{
ДОСЛІДЖЕННЯ МІЦНІСНИХ ХАРАКТЕРИСТИК ВІДБИТКІВ, ПРИПРЕСОВАНИХ ПЛІВКОЮ
}

\begin{abstract}
Подані результати досліджень міцності відбитків, надрукованих цифровим способом друку та припресованих

плівкою. На основі проаналізованих досліджень показано вплив на міцнісні характеристики відбитка паперу, фарби

(тонеру), технологічних режимів обладнання.
\end{abstract}

Ключові слова: оздоблювальні процеси; припресування відбитка; довговічність; цифровий друк; плівка; папір; технологічні режими.

\section{Постановка проблеми}

Споживачі поліграфічної продукції велику увагу приділяють її зовнішньому вигляду. Різноманітність технологій оздоблення дозволяє реалізовувати у виданні задум художника чи дизайнера, надає оригінальності, сприяє його просуванню на ринку. Одним із найрозповсюджених способів покращення зовнішнього вигляду друкованих видань $є$ технологія припресування плівкою. Цей процес підвищує механічну міцність видання, стійкість до стирання фарбового шару на відбитку, захищає його від вологи й забруднення, збільшує довговічність. Останнім часом процеси припресування плівок використовують не тільки на поліграфічних підприємствах, де $\epsilon$ великоформатне устаткування, а й в малих друкарнях, які виготовляються накладами від 1 до 100 примірників, друкуючи цифровим способом друку [1]. Також розширилась сфера

\footnotetext{
(c) $2018 \mathrm{p}$.
}

застосування цієї технології: рекламна аркушева продукція, яка припресована плівкою з двох сторін, книжково-журнальна продукція, яка припресована плівкою з однієї сторони, а також календарі, папки, каталоги, посвідчення тощо.

На якість процесу припресування плівкою істотно впливають властивості паперу, фарби, плівки, відсоток накладання фарби при цифровому друці, технологічні режими обладнання. Щоб звести до мінімуму виникнення дефектів, потрібно враховувати всі фактори, що впливають на технологічний процес. Крім того, видання характеризуються терміном служби, який визначається механічною міцністю на згинання після технологічних операцій бігування, фальцювання, тиснення.

\section{Аналіз попередніх досліджень}

Результати досліджень появи дефектів у процесі припресування 
плівкою та вплив технологічних режимів описано у працях [2-8]. Встановлено, що на якість припресування впливає стан поверхні аркуша паперу, фарба, яка не встигла висохнути після друку, наявність на задрукованому аркуші різних додаткових хімічних речовин, що може призвести до зміни структури фарби в процесі припресування [9].

Особливу увагу приділяється технологічним режимам ламінаторів, а саме температурі каландрів, швидкості, силі притискування. Визначено, що з підвищенням температури, тиску, швидкості зменшується міцність зчеплення паперу з плівкою та відбувається скручування готової продукції [1]. Особливості ламінування відбитків струминним друком відображено у праці [10], а саме розглянуто вплив на якість припресування таких видів плівок, як термічні й самоклейні.

Отже, процес припресування плівкою відбитків, надрукованих цифровим способом друку, й надалі залишається недостатньо дослідженим.

\section{Мета роботи}

Висвітлення результатів дослідження міцності відбитків, надрукованихцифровим способом друку й припресованих плівкою.

\section{Результати проведених досліджень}

Обираючи фарбу для друкування офсетним способом друку, зазвичай враховують подальше припресування, адже при використанні додаткових компонентів перед друкуванням можуть з'явитись проблеми, що призводять до браку. При друкуванні цифровим методом важко вибрати фарбу, яка б мала властивості обумовлені подальшим припресуванням.

Залежно від методу друку, цифрового обладнання, до складу фарби (тонеру), можуть входити парафін, віск та ф'юзерне масло, хімічний склад яких значно погіршує адгезію плівки. Вона починає відшаровуватися від поверхні відбитка суцільно або з поверхневим шаром фарби одразу чи під час післядрукарських операцій (бігування, перфорації, фальцювання). Низька адгезія плівки до задрукованого паперу пояснюється тим, що тонер - полімерна речовина, яка не всотується в папір, порівняно з рідкою фарбою, а лягає зверху задрукованої поверхні паперу. При проходженні технологічного процесу припресування плівкою клей (адгезив) не проникає вглиб основи паперу, а затримується тонером (фарбою) на поверхні відбитка.

Можливі дефекти, які виникають - це руйнація з'єднання між плівкою й папером, після процесів бігування, висікання, а саме прориви, складки, пошкодження поверхні тощо.

Отже, можна вважати, що дефекти виникають за таких причин: несумісність фарби (тонеру) та клею; наявність компонентів, чутливих до дії високих температур; не правильний вибір параметрів проведення технологічного процесу припресування.

Для дослідження міцності паперу після припресування плівкою використовувались відбитки, надруковані цифровим способом друку на папері масою 1 м² 130, 170, 250, 300 г. Для припресу- 
вання використовувалась глянцева (товщиною 25 мкм) й матова (товщиною 30 мкм) плівки виробника Lamiroll (Корея), 3 шириною рулону 91 та 97 см. Технологічний процес припресування виконувався на ламінаторі GMP Excelam-355 Q з таки- ми характеристиками: ширина припресування 330 мм, товщина плівки 25-250 мкм, швидкість 1600 мм/хв., робоча температура $105-160^{\circ} \mathrm{C}$.

На діаграмах рис. 1 показано залежність кількості згинів від маси паперу при накладанні

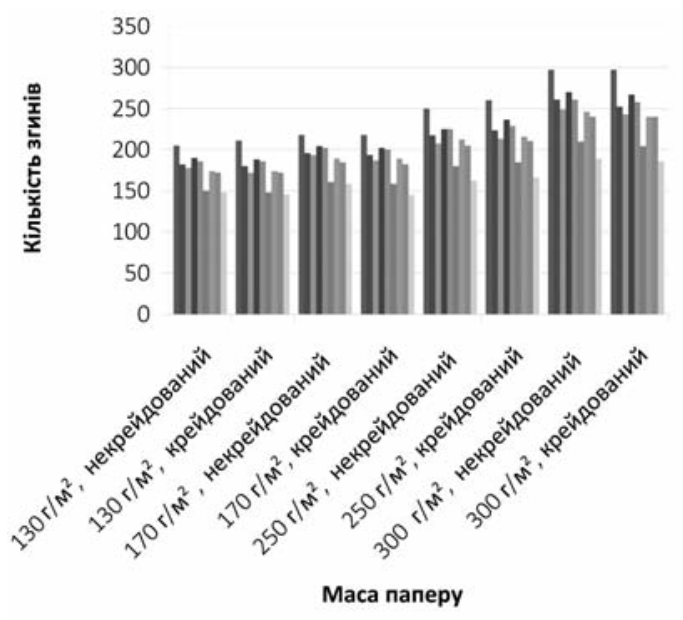

a

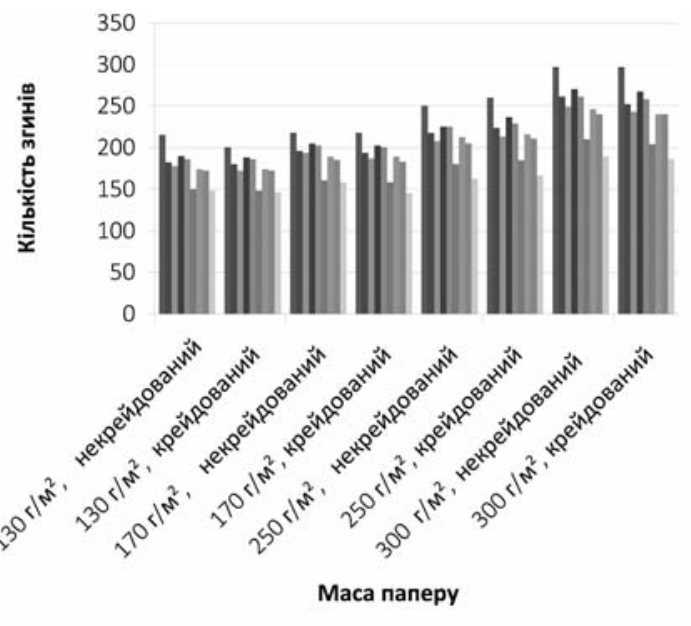

б

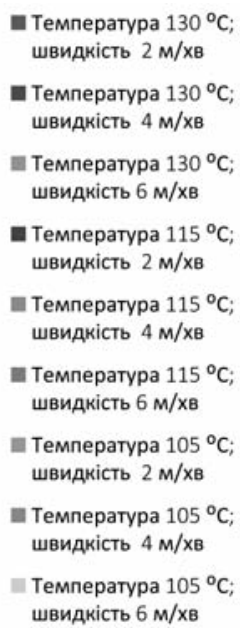

- Temnepatypa $130^{\circ} \mathrm{C}$; швидкість $2 \mathrm{~m} / \mathrm{xв}$

- Teмпература $130^{\circ} \mathrm{C}$; швидкість $4 \mathrm{~m} /$ Хв

- Tемпература $130^{\circ} \mathrm{C}$ швидкість $6 \mathrm{~m} / \mathrm{xв}$

- Tемпература $115^{\circ} \mathrm{C}$ швидкість $2 \mathrm{~m} / \mathrm{xв}$

- Tемпература $115^{\circ} \mathrm{C}$; швидкість $4 \mathrm{~m} / \mathrm{xв}$

- Tемпература $115^{\circ} \mathrm{C}$ швидкість $6 \mathrm{~m} / \mathrm{xв}$

- Температура $105^{\circ} \mathrm{C}$; швидкість $2 \mathrm{~m} /$ хв

- Teмnература $105^{\circ} \mathrm{C}$; швидкість $4 \mathrm{~m} / \mathrm{xв}$

- Temnература $105^{\circ} \mathrm{C}$; швидкість $6 \mathrm{M} / \mathrm{xв}$

Рис. 1. Діаграма залежності міцності на згин від маси паперу та режимів обладнання: a - глянцевої плівки; б - матової плівки, накладання фарб - 0 \% 
фарб 0 \%, варіюванні температури й швидкості обладнання й припресування глянцевою та матовою плівками.

На діаграмах рис. 2 показано залежність кількості згинів від маси паперу при накладанні фарб
100 \% та варіюванні температури й швидкості обладнання й припресування глянцевою та матовою плівками.

На діаграмах рис. 3 показано залежність кількості згинів від маси паперу при накладанні фарб
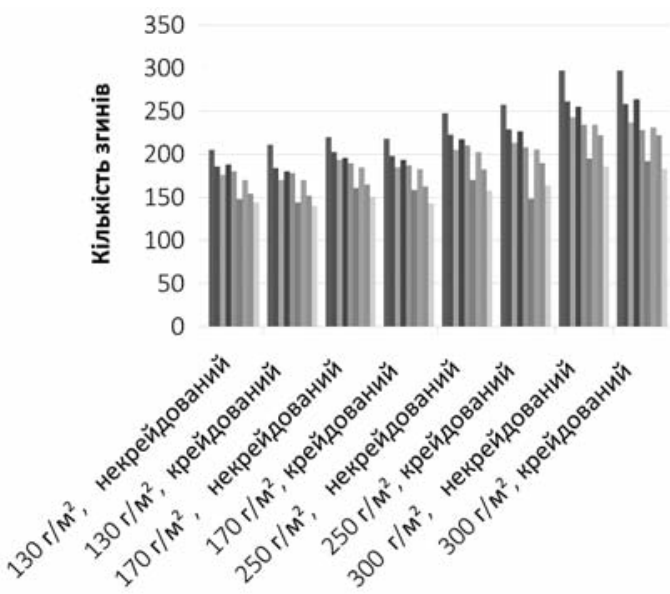

Maca nanepy

a
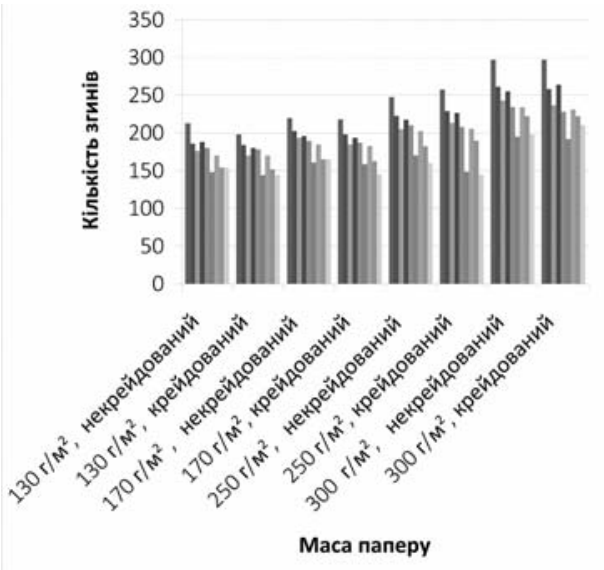

б
- Температура $130^{\circ} \mathrm{C}$ швидкість $2 \mathrm{~m} / \mathrm{xв}$

- Температура $130^{\circ} \mathrm{C}$; швидкість $4 \mathrm{~m} / \mathrm{xв}$

- Температура $130^{\circ} \mathrm{C}$; швидкість $6 \mathrm{~m} / \mathrm{\text {в }}$

- Температура $115^{\circ} \mathrm{C}$; швидкість $2 \mathrm{M} / \mathrm{xв}$

- Температура $115^{\circ} \mathrm{C}$; швидкість $4 \mathrm{~m} / \mathrm{xв}$

ш Температура $115^{\circ} \mathrm{C}$;

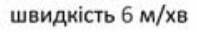

шемпература $105^{\circ} \mathrm{C}$; швидкість $2 \mathrm{~m} / \mathrm{xв}$

तемпература $105^{\circ} \mathrm{C}$; швидкість $4 \mathrm{~m} /$ хв

플 Температура $105^{\circ} \mathrm{C}$; швидкість $6 \mathrm{~m} / \mathrm{xв}$

- Tемпература $130^{\circ} \mathrm{C}$; швидкість $2 \mathrm{~m} / \mathrm{\times в}$

- Температура $130^{\circ} \mathrm{C}$ швидкість $4 \mathrm{~m} / \times 8$

= Temneparypa $130^{\circ} \mathrm{C}$; швидкість $6 \mathrm{~m} / \times 8$

- Температура $115^{\circ} \mathrm{C}$; швидкість $2 \mathrm{M} /$ хв

- Температура $115^{\circ} \mathrm{C}$ швидкість $4 \mathrm{~m} /$ хв

- Температура $115^{\circ} \mathrm{C}$; швидкість $6 \mathrm{~m} /$ ×в

" Температура $105^{\circ} \mathrm{C}$; швидкість $2 \mathrm{~m} /$ хв

= Температура $105^{\circ} \mathrm{C}$; швидкість $4 \mathrm{~m} / \mathrm{Xв}$

= Температура $105^{\circ} \mathrm{C}$; швидкість $6 \mathrm{~m} / \mathrm{xв}$

Рис. 2. Діаграма залежності міцності на згин від маси паперу та режимів обладнання: a - глянцевої плівки; б - матової плівки, накладання фарб - $100 \%$ 
$200 \%$ та варіюванні температури й швидкості обладнання й припресування глянцевою та матовою плівками.

На діаграмах рис. 4 показано залежність кількості згинів від маси паперу при накладанні фарб 300 \% та варіюванні температури й швидкості обладнан- ня й припресування глянцевою та матовою плівками.

\section{Висновки}

За результатами дослідження на міцність відбитка після процесу припресування плівкою істотно впливають властивості паперу та плівки: офсетні папери

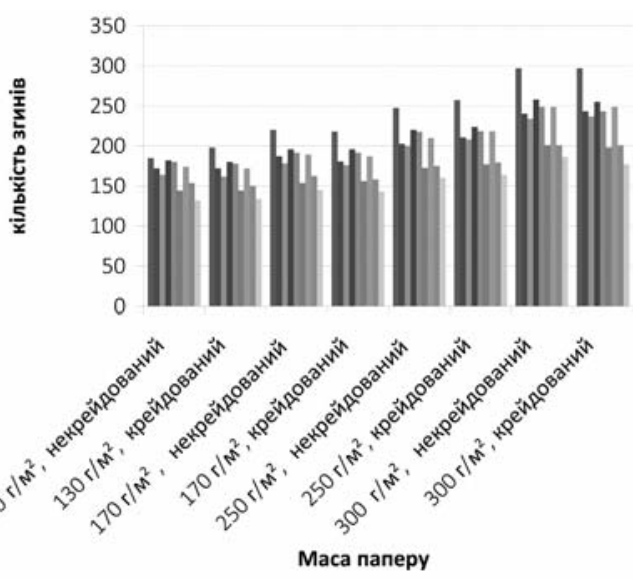

a

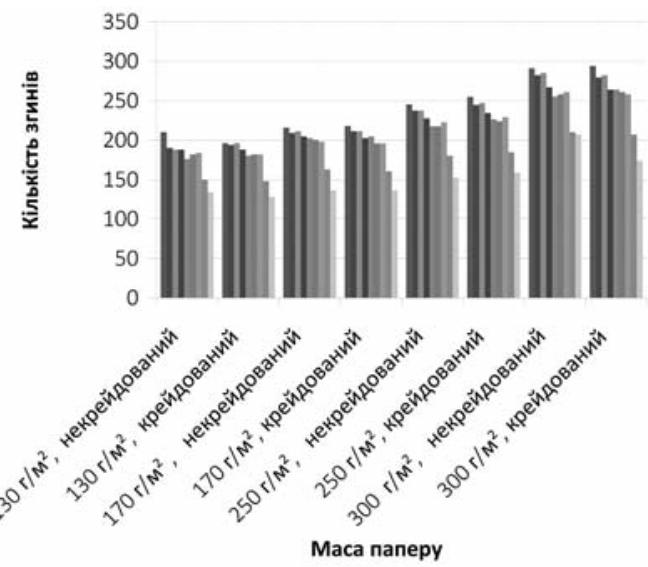

б
- Температура $130^{\circ} \mathrm{C}$ швидкість $2 \mathrm{~m} / \mathrm{xв}$

- Температура $130^{\circ} \mathrm{C}$; швидкість $4 \mathrm{M} / \mathrm{\text {В }}$

- Температура $130^{\circ} \mathrm{C}$ швидкість $6 \mathrm{~m} / \mathrm{\text {в }}$

- Temnepatypa $115^{\circ} \mathrm{C}$; швидкість $2 \mathrm{~m} / \mathrm{xв}$

- Температура $115^{\circ} \mathrm{C}$; швидкість $4 \mathrm{~m} / \mathbf{\text { в }}$

- Температура $115^{\circ} \mathrm{C}$; швидкість $6 \mathrm{~m} / \mathrm{xв}$

- Температура $105^{\circ} \mathrm{C}$; швидкість $2 \mathrm{~m} / \mathrm{\text {в }}$

- Температура $105^{\circ} \mathrm{C}$; швидкість $4 \mathrm{~m} / \times \mathbf{x}$

- Tемпература $105^{\circ} \mathrm{C}$;

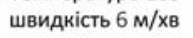

- Температура $130^{\circ} \mathrm{C}$; швидкість $2 \mathrm{~m} /$ хв

- Температура $130^{\circ} \mathrm{C}$; швидкість $4 \mathrm{M} / \times \mathrm{B}$

ш Температура $130{ }^{\circ} \mathrm{C}$; швидкість $6 \mathrm{~m} / \mathrm{xв}$

- Температура $115^{\circ} \mathrm{C}$; швидкість $2 \mathrm{M} / \mathrm{xв}$

- Температура $115^{\circ} \mathrm{C}$; швидкість $4 \mathrm{M} /$ хв

- Температура $115^{\circ} \mathrm{C}$; швидкість $6 \mathrm{~m} / \mathrm{\text {в }}$

- Температура $105^{\circ} \mathrm{C}$; швидкість $2 \mathrm{~m} / \mathrm{xв}$

- Температура $105^{\circ} \mathrm{C}$; швидкість $4 \mathrm{M} / \mathrm{\text {хв }}$

II- Температура $105^{\circ} \mathrm{C}$; швидкість $6 \mathrm{M} / \mathrm{\times в}$

Рис. 3. Діаграма залежності міцності на згин від маси паперу та режимів обладнання: a - глянцевої плівки; б - матової плівки, накладання фарб - 200 \% 
припресовані матовою плівкою витримують більшу кількість згинів, ніж крейдовані папери припресовані глянцевою плівкою, в середньому більше на $10 \%$. За температури $115-130^{\circ} \mathrm{C}$ та швидкості 2-4 м/хв. задруковані аркуші паперу, припресовані плів- кою, витримують найбільшу кількість згинів 250-300 разів, що характеризує високу міцність відбитків. Найменший вплив на міцність відбитка має накладання тонеру (0 \% до $300 \%$ ), в середньому різниця складає 20-30 згинів між досліджуваними зразками.

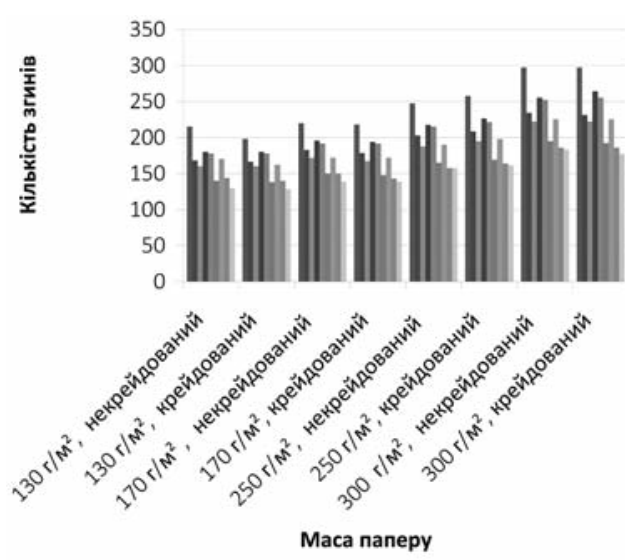

a

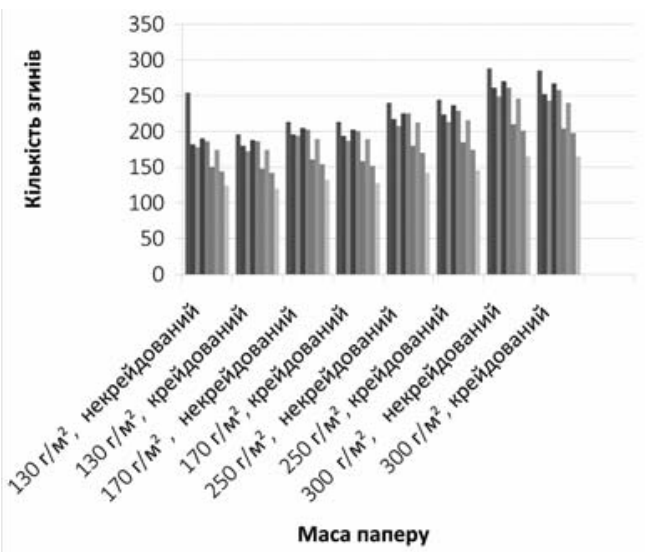

б
- Tемпература $130^{\circ} \mathrm{C}$ швидкість $2 \mathrm{~m} / \mathbf{\times в}$

- Температура $130^{\circ} \mathrm{C}$; швидкість $4 \mathrm{M} /$ хв

ш Температура $130^{\circ} \mathrm{C}$; швидкість $6 \mathrm{~m} / \mathrm{хв}$

- Температура $115^{\circ} \mathrm{C}$; швидкість $2 \mathrm{~m} / \times \mathbf{8}$

ш Температура $115^{\circ} \mathrm{C}$; швидкість $4 \mathrm{M} / \times \mathbf{B}$

- Температура $115^{\circ} \mathrm{C}$ швидкість $6 \mathrm{~m} / \mathrm{\text {хв }}$

- Температура $105^{\circ} \mathrm{C}$; швидкість $2 \mathrm{~m} / \mathrm{\times в}$

- Температура $105^{\circ} \mathrm{C}$; швидкість $4 \mathrm{M} /$ хв

= Температура $105^{\circ} \mathrm{C}$; швидкість $6 \mathrm{~m} / \mathrm{xв}$

- Температура $130^{\circ} \mathrm{C}$ швидкість $2 \mathrm{M} / \mathbf{\text { хв }}$

- Температура $130^{\circ} \mathrm{C}$ швидкість $4 \mathrm{~m} /$ хв

- Температура $130^{\circ} \mathrm{C}$. швидкість $6 \mathrm{~m} / \mathrm{xв}$

- Температура $115^{\circ} \mathrm{C}$; швидкість $2 \mathrm{M} / \mathrm{\text {в }}$

- Температура $115^{\circ} \mathrm{C}$

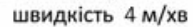

- Температура $115^{\circ} \mathrm{C}$ швидкість $6 \mathrm{~m} / \mathrm{xв}$

- Температура $105^{\circ} \mathrm{C}$; швидкість $2 \mathrm{~m} / \mathrm{xв}$

- Температура $105^{\circ} \mathrm{C}$ швидкість $4 \mathrm{~m} / \mathrm{Xв}$

II Температура $105^{\circ} \mathrm{C}$; швидкість $6 \mathrm{~m} / \mathrm{\text {в }}$

Рис. 4. Діаграма залежності міцності на згин від маси паперу та режимів обладнання: a - глянцевої плівки; б - матової плівки, накладання фарб $-300 \%$ 


\section{Список використаної літератури}

1. Кирилюк А. В. Технологічні особливості ламінування листівок / А. В. Кирилюк, О. В. Зоренко, Т. В. Розум // Поліграфія і видавнича справа. 2011. № 4. С. 90-101.

2. Гавенко С. Оздоблення друкованої продукції: технологія, устаткування, матеріали / С. Гавенко, Е. Лазаренко, Б. Мамут. Київ: УАД, 2003. 286 с.

3. Гавенко С. Дослідження міцності ламінування відбитків, отриманих струминним способом / С. Гавенко, М. Мартинюк // зб. наук. пр. «Квалілологія книги»: матеріали конФ. Львів: УАД, 2007. С. 23-24.

4. Припресовування плівки. Ламінування // Друкуймо: Вісн. поліграфії. 2003. № 1. C. $20-27$.

5. Чепурна К. О. Дослідження адгезії поліпропіленових плівок до поверхні відбитків електрографічного друку в процесі ламінування / К. О. Чепурна, О. С. Оліяненко // Технологія і техніка друкарства. 2016. Вип. 4. С. 39-48. Режим доступу: http://nbuv.gov.ua/UJRN/Titd_2016_4_8.

6. Кирилюк А. В. Дослідження ламінування листівок / А. В. Кирилюк, О. В. Зоренко // Технологія і техніка друкарства. 2011. № 4(34). С. 46-56. Режим доступу: http://ttdruk.vpi.kpi.ua/article/view/33487.

7. Гавенко С. Ф. Дослідження дефектів лакованих поверхонь книжкових обкладинок / С. Ф. Гавенко, О. М. Мізюк // Технологія і техніка друкарства. К.: НТУУ «КПІ» ВПІ, 2003. № 1. С. 14-17.

8. Байдак О. Ю. Сучасний стан розвитку декоративного лакування / О. Ю. Байдак, А. П. Гавриш, Р. А. Хохлова, В. В. Калініченко // Поліграфія і видавнича справа. 2011. № 3. С. 162-169. Режим доступу: http://nbuv.gov.ua/UJRN/Pivs 2011321.

9. Коротка В. О. Використання методів математичної статистики для оцінки якості відбитків трафаретного друку на оксо-біодеградуюючих плівках / В. О. Коротка, К. Ф. Базилюк, Р. С. Зацерковна // Наукові записки [Українська академія друкарства]. 2014. № 3(48). С. 86-90.

10. Гавенко С. Ф. Технологія ламінування друкарських відбитків: навч. посіб. / С. Ф. Гавенко, М. С. Мартинюк. Львів: УАД, 2008. 286 с.

\section{References}

1. Kyryliuk, A. V. \& Zorenko, O. V. \& Rozum, T. V. (2011). Tekhnolohichni osoblyvosti laminuvannia lystivok. Journal of Polihrafiia $i$ vydavnycha sprava, 4, 90-101 [in Ukrainian].

2. Havenko, S. \& Lazarenko, E. \& Mamut, B. (2003). Ozdoblennia drukovanoi produktsii: tekhnolohiia, ustatkuvannia, materialy. Kyiv: UAD, 286 p. [in Ukrainian].

3. Havenko, S. \& Martyniuk, M. (2007). Doslidzhennia mitsnosti laminuvannia vidbytkiv, otrymanykh strumynnym sposobom. Journal of Kvalilolohiia knyhy, 23-24 [in Ukrainian].

4. (2003). Prypresovuvannia plivky. Laminuvannia. Journal of Drukuimo: Visnyk polihrafii, 1, 20-27 [in Ukrainian].

5. Chepurna, K. O. \& Oliianenko, O. S. (2016). Doslidzhennia adhezii polipropilenovykh plivok do poverkhni vidbytkiv elektrohrafichnoho druku v protsesi laminuvannia. Journal of Tekhnolohiia i tekhnika drukarstva, 4, 39-48. Retrieved from http://nbuv.gov.ua/UJRN/Titd_2016_4_8 [in Ukrainian]. 
6. Kyryliuk, A. V. \& Zorenko, O. V. (2011). Doslidzhennia laminuvannia lystivok. Journal of Tekhnolohiia i tekhnika drukarstva, 4(34), 46-56. Retrieved from http://ttdruk.vpi.kpi.ua/article/view/33487 [in Ukrainian].

7. Havenko, S. F. \& Miziuk, O. M. (2003). Doslidzhennia defektiv lakovanykh poverkhon knyzhkovykh obkladynok. Journal of Tekhnolohiia i tekhnika drukarstva, 1, 14-17 [in Ukrainian].

8. Baidak, O. Yu. \& Havrysh, A. P. \& Khokhlova, R. A. \& Kalinichenko, V. V. (2011). Suchasnyi stan rozvytku dekoratyvnoho lakuvannia. Journal of Polihrafiia $i$ vydavnycha sprava, 3, 162-169. Retrieved from http://nbuv.gov.ua/UJRN/Pivs 2011321 [in Ukrainian].

9. Korotka, V. O. \& Bazyliuk, K. F. \& Zatserkovna, R. S. (2014). Vykorystannia metodiv matematychnoi statystyky dlia otsinky yakosti vidbytkiv trafaretnoho druku na okso-biodehraduiuiuchykh plivkakh. Journal of Naukovi zapysky, 3(48), 86-90 [in Ukrainian].

10. Havenko, S. F. \& Martyniuk, M. S. (2008). Tekhnolohiia laminuvannia drukarskykh vidbytkiv. Lviv: UAD, 286 p. [in Ukrainian].

\section{Представлены результаты исследований прочности оттисков, напечатанных цифровым способом печати и при- прессованых пленкой. На основе проанализированных исследований показано влияние на прочностные характеристики оттиска бумаги, краски (тонера), технологических режимов оборудования.}

Ключевые слова: отделочные процессы; припрессовка оттиска; долговечность; цифровая печать; пленка; бумага; технологические режимы.

The researches results of the strength of the sheets printed by the digital printing and with the laminated film are given. On the analyzed studies basis, the influence on the strength characteristics of the paper imprint, ink (toner), technological aspects of the equipment is shown.

Keywords: postprinting; laminating imprint; durability; digital printing; film; paper; technological modes. 